\title{
Diyabette Tıbbi Beslenme Tedavisinin Uygulanması ve Diyetisyenin Sorumlulukları
}

\author{
Implementation of Medical Nutrition Therapy in Diabetes and Responsibilities of Dietitian
}

\section{Emel Özer ${ }^{1}$}

Geliş tarihi/Received: 08.10.2019 • Kabul tarihi/Accepted: 27.12.2019

\section{ÖZET}

Diyabet, endişe verici düzeye ulaşmış önemli bir sağlık sorunudur. Tıbbi beslenme tedavisi (TBT) diyabet yönetiminin önemli bir bileşenidir. Rehberler, TBT’nin diyabet ve beslenme konusunda deneyimli bir diyetisyenden sağlanması gerektiğini vurgulamaktadır. TBT, enerji hesaplamasına ve makro besin ögelerinin dağılımına odaklı olarak hazırlanmış veya önceden basılmış bir diyet listesi değildir. Besin tüketimi ve beslenme davranışının değerlendirilmesine dayalı olarak beslenme önerilerinin belirlenmesi diyetisyenin sorumluluğudur. Tedavinin sonuçları tanımlanmalı ve beslenme müdahalelerinin etkinliği sürekli olarak değerlendirilmelidir. Diyetisyenlerden sağlanan TBT’nin metabolik kontrol üzerinde önemli derecede etkin olduğu bilinmektedir. Bu derlemede güncel bilimsel verilere dayalı olarak TBT uygulama aşamaları ve bu süreçte diyetisyenin sorumlulukları ele alınmıştır.

Anahtar kelimeler: Diyabet, tıbbi beslenme tedavisi, beslenme bakım süreci, diyetisyen, metabolik kontrol

\begin{abstract}
Diabetes is an important health problem that has reached an alarming level. Medical nutrition therapy (MNT) is an important component of diabetes management. The guidelines emphasize that MNT should be provided by a dietitian experienced in diabetes and nutrition. MNT is not a diet list prepared or pre-printed with a focus on energy calculation and distribution of macronutrients. It is the responsibility of the dietitian to determine the nutrition recommendations based on food consumption and nutritional behavior assessmemt. Outcomes must be identified and the effectiveness of nutrition interventions continually evaluated. MNT provided by dietitians is known to be significantly effective on metabolic control. In this review, MNT application stages and dietitian responsibilities in this process are discussed based on current scientific data.
\end{abstract}

Keywords: Diabetes, medical nutrition therapy, nutrition care process, dietitian, metabolic control

\section{GíRiş}

Diyabet, insülin eksikliği ya da insülin etkisindeki defektler nedeniyle organizmanin karbonhidrat (KH), yağ ve proteinlerden yeterince yararlanamadı̆̆ı, sürekli tıbbi bakım gerektiren, kronik, geniş spektrumlu bir metabolizma bozukluğudur (1).
Diyabet, endişe verici seviyelere ulaşan küresel ve ulusal prevalansı ile önemli bir sağlık sorunu olarak kabul edilmektedir (2).

Uluslararası Diyabet Federasyonu'nun (International Diabetes Federation [IDF]) 2019 yllı verilerine göre

1. İletişim/Correspondence: Diyabet Diyetisyenliği Derneği, İstanbul, Türkiye E-posta: emelozer@yahoo.com • ํ https://orcid.org/0000-0002-4394-8761 
dünya genelinde 2000 yllında diyabetle yaşayanların sayısı 150 milyon iken günümüzde 20-79 yaş grubunda yaklaşık yarım milyar insan diyabetle yaşamaktadır. Bu sayının 2030 yılında 570 milyona, 2045 yılında ise 700 milyona ulaşacağı öngörülmektedir. Küresel diyabet prevalansı 20-79 yaş grubu için \%9.3'dür. Diyabetli bireylerin yaklaşı \%30’u 65-99 yaş grubunda olup, bu yaş grubunda diyabet prevalansı \%19.9'dur. 0-19 yaş grubunda olan tip 1 diyabetlilerin sayısı ise bir milyonu aşmıştır. Küresel diyabet prevalansının ve diyabetli yaşlı nüfusun artması ile birlikte diyabetle ilişkili sağlık harcamaları da artmıştır. Dünya genelinde diyabetin direk maliyeti 2017 yılına kıyasla \%4.5 oranında artış göstermiş ve 760 milyar dolara ulaşmıştır. IDF Avrupa bölgesi kapsamında en yüksek diyabet prevalansına sahip olan ülke Türkiye'dir ve Avrupa'da diyabet nüfusu en fazla olan ülke sıralamasında 3. sırada yer almaktadır (2).

'Türkiye Diyabet Epidemiyoloji Çalışması (TURDEP)I' in 1998 yılı sonuçları, 20 yaş ve üzeri yetişkinlerde diyabet prevalansının \%7.2, bozulmuş glukoz toleransı (BGT) prevalansının \%6.7 olduğunu göstermiştir. TURDEP II'nin sonuçlarına göre 12 yllda diyabet prevalansı \%90 artarak \%13,7’ye, BGT prevalansı \%106 artarak \%13.8'e ulaşmıştır (3).

Gerek diyabetin önlenmesi gerek ise tedavisine yönelik olarak ulusal düzeyde hazırlanan kanıta dayalı tedavi rehberlerine, gelişen diyabet teknolojilerine ve artan tıbbi tedavi seçeneklerine rağmen hem diyabet prevalansı artmakta hem de diyabetli bireylerde metabolik kontrol yeterince sağlanamamaktadır (2-5). DEPAC (Diabetes Secondary Care in Central and Eastern Europe) çalışmasinın bulguları, tip 1 diyabetlilerin \%13.1'inin, tip 2 diyabetli bireylerin \%21.4’ünün hedeflenen HbA1c düzeylerine ulaştığını bildirilmiştir (4). Avrupa bölgesinden dokuz ülkenin katıldığı PANORAMA çalışmasının bulgularına göre tip 2 diyabetli bireylerin \%37.4'ünün HbA1c düzeyleri $\geq \% 7$ 'dir ve Türkiye'de bu oranın \%52 olduğu saptanmıştır (5). Araştırmacılar, diyabetli bireylerin yaşam tarzı değişikliğine ve tıbbi tedaviye yönelik önerileri günlük yaşama aktarma becerisinin metabolik kontrol hedeflerine ulaşılmasında etkili faktörler olduğunu vurgulamıştır (5).

Diyabet yönetimi bir ekip çalışmasıdır. Ekip üyeleri olan hekim, diyetisyen, hemşire ve diğer sağlık çalışanları uzmanlık alanları ile ilişkili olarak tedaviye katılır ve metabolik kontrolün sağlanması için ekip çalışmasının merkezinde yer alan diyabetli bireyi destekler. Beslenme tedavisinin amacı diyabetli bireylerin öz yönetimleri için gerekli bilgiyi vermek, öz yönetim becerilerini geliştirmek, mevcut sorunlara yönelik çözüm yolları geliştirmek ve sonuç olarak metabolik kontrolü sağlamak ve yaşam kalitesini yükseltmektir $(6,7)$. Bu derlemede, güncel bilimsel verilere dayalı olarak TBT uygulama aşamaları ve bu süreçte diyetisyenin sorumlulukları ele alınmıştır.

\section{Tıbbi Beslenme Tedavisinin Uygulanması}

Tıbbi beslenme tedavisi (TBT) diyabet tedavisinin ayrılmaz öğesidir ve beslenme tedavi sürecinin kanıta dayalı uygulamasıdır (8). Amerikan Beslenme ve Diyetetik Akademisi (Academy of Nutrition and Dietetics) 'nin tanımına göre TBT 'hastalıkların önlenmesi, gecikmesi veya yönetimiyle sonuçlanan beslenme değerlendirmesi/yeniden değerlendirme, beslenme tanısı, beslenme müdahalesi ile beslenme izlem ve değerlendirme aşamalarından birinin veya birkaçının sağlanmasıdır'. Akademi, TBT’nin Beslenme Terminolojisi Referans Kılavuzu'nda tanımlandığı gibi, besin ve/veya besin ögelerinin, beslenme eğitimi, beslenme danışmanlığı ve beslenme bakımının koordinasyonu olmak üzere tüm beslenme müdahalesi alanlarını kullandığını bildirmektedir (9).

Beslenme tedavi süreci (BTS) diğer bir ifade ile TBT uygulama aşamaları, yüksek kaliteli beslenme tedavisi sağlamak için sistematik bir yaklaşımdır (9). Birbiriyle ilişkili dört ayrı adımdan oluşur; i) beslenme değerlendirmesi, ii) beslenme tanısı, iii) beslenme müdahalesi ve iv) beslenme izlemi ve değerlendirme (9-11). Her adım bir öncekini temel alsa da, süreç doğrusal değildir (9). Bu aşamaların uygulanması diyetisyen ve diyabetli bireyin iletişim içinde olmasını, işbirliği yapmasını gerektirir. Diyetisyen 
gelişmiş beslenme ve diyetetik bilgisine, eleştirel düşünme becerisine sahip olmall, tedaviyi planlarken kanıta dayalı önerileri ve etik kodları dikkate almalı, tedavi boyunca gerekli kayıtları tutmalı, tedavinin etkinliğini değerlendirmelidir (Şekil 1) (11).

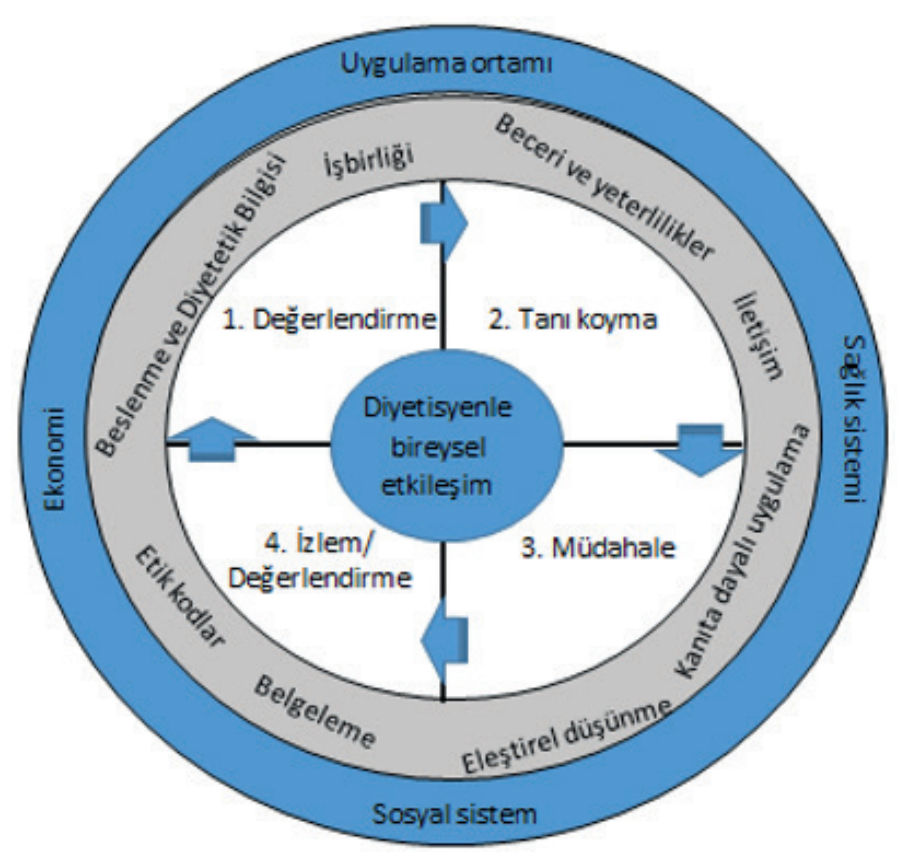

Şekil 1. Beslenme Tedavisi Süreci (11)

Değerlendirme: Beslenmeyle ilgili sorunları ve nedenlerini belirlemek için gereken önemli ve ilgili verileri toplamak, sinıflandirmak ve sentezlemek için sistematik bir yaklaşımdır $(11,12)$. Tedavinin ileri aşamalarında elde edilen verilerin önceki verilerle karşılaştırmasını, davranış değişikliğinin değerlendirilmesini, beslenme tanısının belirlenmesini sağlar. $\mathrm{Bu}$ aşamada diyetisyenler tedavi planını formüle etmek için tip 1 diyabet ve tip 2 diyabetli yetişkinlerde aşağıda belirtilen verileri sağlamalıdır. Veriler doğrudan diyabetli birey veya ailesi ile yapılan görüşme, gözlem ve antropometrik ölçümlerle, sağlık kurumu kayıtlarından, yönlendirmeyi yapan hekim aracılığıyla sağlanabilir (12).

Biyokimyasal veriler, tıbbi testler ve ilaç kullanımı: Diyabet tipi, glisemik kontrol durumu, lipit profili, kan basıncı, kronik böbrek hastalığının varlığı, glukoz ve lipit düşürücü ilaçların kullanımı, besin (bitkisel, vitamin ve mineral) takviyelerinin ve tamamlayıcı veya alternatif tedavilerin kullanımıdır.

Beslenme odaklı fiziksel bulgular: Boy uzunluğu, vücut ağırlığı, beden kütle indeksi (BKİ), bel çevresi, injeksiyon bölgeleri, vücut ağırlık öyküsü, genel görünümü, çiğneme ve yutma problemleri, iştah durumudur.

Diyabetli bireyin geçmişi: Genel sağlık ve demografik bilgileri; sosyal ve kültürel tercihleri; sağlık okuryazarlığı ve aritmetiği kullanma becerisi; eğitim durumu ve mesleği; diyabete yönelik bilgisi, inançları, tutumları, öz-yeterliliği, davranış değişikliği yapma istekliliği ve yeteneği; fiziksel aktivite düzeyi; bireyin ve ailesinin beslenme ile ilgili tıbbi ve sağlık öyküsü; diğer tıbbi veya cerrahi tedaviler; varsa uyguladığı beslenme tedavisi önerileridir.

Beslenme öyküsü: Enerji alımı, besin tüketimi; porsiyon boyutları; öğün sayısı ve öğün-ara öğün aralığı; karbonhidrat (KH), lif, yağ türleri, miktarları, protein, mikro besin ögesi alımı; alkol alımı; yeme ortamı, sağlıklı besinlere erişimi ve ev dışında yeme davranışı, tercihleridir (10-12).

Diyabetli bireyin psikolojik ve sosyal durumunun değerlendirilmesi, diyabette tıbbi yönetimin bir parçası olmalıdır. Bireyin hastalığa ilişkin tutumları, tedavi sonuçları için beklentileri, duygu durumu, genel ve diyabetle ilişkili yaşam kalitesi, kaynakları (finansal, sosyal ve duygusal), psikiyatrik öykü ve diyabet yönetimini zorlaştırabilecek ortak komorbid durumları ele alınmalıdır (10).

Beslenme tanısı belirleme ve hedef saptama: Değerlendirme aşaması sonucunda diyetisyen tedavisinden sorumlu olduğu diyabetli bireyin mevcut beslenme sorunlarını tanımlar $(10,11,13)$. Beslenme tanısı, gereksinime uygun olmayan $\mathrm{KH}$ alımı, yağ tüketiminin gereksinim düzeylerinden fazla olması, öğünden öğüne değişen $\mathrm{KH}$ alımı, glisemik indeksi (GI) yüksek besinlerin tüketim sıklığının fazlalığı vb. şekilde saptanabilir. Diyetisyen, saptamış olduğu beslenme tanısının etiyolojisini ve tanıyla ilişkili bulguları ve belirtileri tanımlar $(11,13)$. 
Bulgular diyabetli bireyin ifade ettiği değişikliklerdir, belirtiler ise eğitimli bir diyetisyenin gözlemleridir (11). Örnek ile açıklanacak olursa beslenme tanısı ‘öğle yemeğinde yağ alımı fazla’ olarak belirlenmiş yetişkin tip 2 diyabetli bir bireyde, beslenme tanısının etiyolojisi ‘öğle yemeğinin ev dışında yenilmesi, yağ içeriği yüksek menü seçimi’ olarak tanımlanmış olabilir. Tanıyla ilgili bulgu ve belirtiler ise 'öğleden sonra acıkma hissi, akşam yemeğinde yenilen besinlerin porsiyonunda artış, akşam yemeği sonrası tokluk kan glukoz düzeylerinde yükselme, mevcut durumun diyabetli bireyde yarattığı huzursuzluk ve endişe' şeklinde saptanmış olabilir.

Diyetisyen, eleştirel düşünme becerisine sahip olmalı ve sağlamış olduğu değerlendirme verilerinin belirlemiş olduğu beslenme tanısını, tanıyla ilişkili etiyolojiyi, bulgu ve belirtileri destekleyip desteklemediğini kontrol etmelidir. Gerekirse değerlendirme aşaması tekrarlanmalı, mevcut verilerdeki eksiklikler tamamlanmalıdır $(11,13)$.

Her diyabetli birey için nihai hedef kan şekeri kontrolünü sağlamaktır. Değerlendirmenin iyi yapılmış olması kan şekeri kontrolünün sağlanmasını engelleyen beslenme davranışı veya davranışları ile engelleyici etkenlerin belirlenmesini ve mevcut davranışların değiştirilmesine yönelik doğru çözüm yollarının saptanmasını sağlar. Beslenme tanısına ve bireysel tedavi hedeflerine yönelik ulaşlabilir ve uygulanabilir davranışlar diyetisyen ve diyabetli birey tarafindan birlikte belirlenir (11). Tüm bu bilgiler ışığında görülmektedir ki tedavi hedefi bireyden bireye değişir.

Beslenme müdahalesi, beslenme öz yönetim eğitimi: Beslenme müdahalesi; beslenmeyle ilgili bir davranışı, risk faktörünü, çevresel durumu veya sağlık durumunun bir yönünü değiştirmek amacıyla tasarlanmış, amaçlı olarak planlanmış bir eylemdir. Beslenme müdahalesi birbiriyle ilişkili iki bileşenden oluşur. Bunlar planlama ve müdahaledir. Her iki bileşenin kapsamı Tablo 1'de yer almaktadır. Beslenme müdahalesi, temel olarak saptanan beslenme tanısı veya beslenme etiyolojisine çözüm sağlamaya ve daha az sıklıkla belirti ve bulguları hafifletmeye yöneliktir $(11,14)$.

Müdahale aşamasında diyabetli birey müdahale hedeflerine ulaştıysa takibe alınır. Gerekli değişiklikleri yapmaya hazır ve istekli değilse diyetisyen planlanan müdahalenin bir parçası olarak diyabetli bireyi tedavinin bu bölümünden taburcu edebilir. Tüm koşullarda diyabetli bireyin mevcut durumu, hekimi ile paylaşılmalıdır (11).

Tablo 1. Beslenme müdahalesinin bileşenleri ve kapsamı (11)

\section{Beslenme müdahalesinin bileşeni}

Müdahale kapsamı

- Aciliyet durumuna, sağlayacağı etkiye ve mevcut kaynaklara dayalı müdahalelere öncelik verin.

- Mevcut referans değerlerini / standartlarını, kanıta dayalı beslenme rehberlerini, diyabetli bireyin sağlık durumu ile beslenme tanısını temel alan bireyselleştirilmiş enerji ve besin ögesi gereksinimine, besin seçimine dayalı

1. Planlama bir beslenme planı oluşturun.

- Her tanıya ait müdahalenin hedeflerini belirlemek için diyabetli birey ile işbirliği yapın.

- Sorunun etiyolojisine odaklanan, en güncel bilgi ve kanıtlara dayanarak etkili olduğu bilinen müdahale stratejilerini seçin.

- Beslenme görüşmelerinin zamanını, sıklığını, süresini tanımlayın.

- Tedavi planını uygulamak için diyabetli birey ile işbirliği yapın.

- Tedavi planını açıklayın.

2. Müdahale

- Tedavi planını gereksinimler doğrultusunda değiştirin.

- İzleyin ve tedavi planının uygulandığını doğrulayın.

- Koşullardaki değişikliklere veya uygulanan tedavi planına verilen yanıta dayalı olarak stratejileri gözden geçirin. 
Diyetisyenin müdahale aşamasında kullanacağı kaynaklar profesyonel kuruluşların uluslararası ve ulusal düzeyde hazırlanmış olduğu kanıta dayalı tedavi rehberleri ve/veya Cochrane kütüphanesi, güncel araştırma kaynakları, diyabet yönetimi ile ilişkili çalışmaların ve kalite geliştirme projelerinin sonuçlarıdır (11). Ülkemizde, Diyabet Diyetisyenliği Derneği tarafından yayınlanmış olan 'Diyabetin Önlenmesi ve Tedavisinde Kanıta Dayalı Beslenme Tedavisi Rehberi’ diyabet odaklı çalışan diyetisyenler için ulusal kaynak niteliğindedir (15).

Müdahale aşamasında bireye uygun öğün planlama yöntemi (beslenme piramidi, tabak modeli, değişim listeleri, KH sayımı) ve beslenme öz yönetim eğitimi planlanır. Tanıya dayalı olarak planlanan beslenme önerileri medikal tedavi ile ilişkilendirilmelidir (Tablo 2) $(1,7,15)$.

Beslenme öz yönetim eğitimi, saptanan hedefe ulaşmayı kolaylaştıracak, bireye özgü olarak belirlenen öğün planlama yönteminin uygulanmasını destekleyecek, diyabet ve beslenme tedavisi konusunda bilgi ve uygulama becerisi kazandıracak içerikte olmalıdır. Beslenme öz yönetim eğitimi kapsamında yer alması gereken öncelikli konular diyabetli bireyin gereksinimlerine göre değişmekle birlikte eğitim içeriği ile ilişkili temel başlıklar Tablo 3’de özetlenmiştir $(7,15)$.

İzlem ve değerlendirme: $\mathrm{Bu}$ aşamada beslenme tanısı, müdahale planları ve hedefleri ile ilgili sonuçlar/ göstergeler değerlendirilir. Bu sonuç ve göstergeler

Tablo 2. Tıbbi tedaviyle ilişkili beslenme önerileri $(1,7,15)$

Müdahale kapsamı

- Sulfonilüre, glinid grubu ilaç kullananlar: İnsülin salgılatıcı olarak tanımlanan bu grup ilaçların yan etkilerinin başında hipoglisemi ve vücut ağırlık artışı gelir. Öğün ve ara öğünlerde karbonhidrat alımı değişmemeli, hipoglisemi riskini azaltmak için öğünlerde mutlaka önerilen miktarda karbonhidrat alımını sağlayacak besin tüketilmeli, öğün atlanmamalı, egzersiz veya fiziksel aktivite düzeyinin artmasına bağlı olarak gelişebilecek hipoglisemi riskini azaltmak için diyabetli birey yanında karbonhidrat içeren besin (sofra şekeri, lif içermeyen meyve suyu) bulundurmalıdır.

- Biguanid (metformin), tiazolidindion kullananlar: Biguanidler (Metformin) gastrointestinal sistem yan etkileri nedeniyle öğünün zamanında alınmasını ve öğün içeriğinin tam olarak tüketilmesini etkileyebilir. Eğer yan etkiler birkaç hafta devam ediyorsa doktora danışılmalıdır. Yan etkilerinden biri $\mathrm{B}_{12}$ vitamini eksikliği olduğundan yetersizliği değerlendirilmelidir. Tiazolidindion grubu ilaçların yan etkileri arasında ödem, vücut ağırlık artışı, düşük dansiteli lipoprotein (LDL) kolesterol düzeylerinde yükselme yer almaktadır. Vücut ağırlık yönetimi ve kardiyovasküler risk değerlendirmesi yapıldığında, beslenme tedavisinin sonuçları değerlendirildiğinde ilaca bağlı olası yan etkiler göz önüne alınmalıdır. Her iki ilaç grubu hipoglisemiye neden olmaz. Diyabetli birey biguanid grubu ilaç ile birlikte insülin sekretogogları veya insülin tedavisi alıyorsa hipoglisemi ve tedavisi konusunda bilgi verilmeli, öğünlerde alması gereken karbonhidrat miktarının önemi açıklanmalıdır.

- Alfa glukosidaz inhibitörü kullananlar: İlaç öğünle birlikte alınmalıdır. Tedaviye insülin sekretogogları veya insülin eklenirse hipoglisemi ve tedavisi konusunda bilgi verilmelidir. Karbonhidrat alımı gastrointestinal sistem yan etkilerine bağlı olarak tolere edilebilir.

- Glukagon benzeri peptid-1 reseptör agonistleri (GLP-1 agonistleri) kullananlar: Hipoglisemi riski düşük olmakla birlikte bulantı, kusma, diare gibi yan etkilerinin varlığı besin tüketimini olumsuz etkileyebilir.

- Karışım insülin tedavisi alan tip 2 diyabetliler: İnsülin injeksiyon zamanı ve öğün zamanı ve öğünde alınan karbonhidrat miktarı günden güne değişmemeli, aynı olmalıdır. Hipoglisemiyi önlemek için öğün atlanmamalıdır. Egzersiz nedeni ile gelişebilecek hipogliseminin tedavisi için diyabetli bireyin yanında karbonhidrat içeren besin (sofra şeker, lif içermeyen meyve suyu) bulundurması gerekir. İnsülinin anabolizan etkisi nedeniyle özellikle fazla kilosu ve şişmanlığı olan bireylerin karbonhidrat alımı yanı sıra yağ alımına dikkat etmesi önerilir.

- Çoklu doz insülin injeksiyonu yapan veya insülin pompası kullananlar: Öğünde tüketilen karbonhidrat miktarı ile öğün bazında alınan insülin dozunun eşleşmesine fırsat veren karbonhidrat sayımı adlı öğün planlama yöntemi öğretilmelidir. Kısa etkili insülin kullananlarda ara öğün alımı insülin etki profili nedeniyle gelişebilecek hipoglisemi riskinin önlenmesine yardımcı olur. Hızlı etkili insülin kullananlarda ara öğünlerde 15 g’dan fazla karbonhidrat alımı problem olabilir, ek insülin uygulaması gerektirebilir. 
Tablo 3. Beslenme eğitiminde öncelikli konular ve öneriler $(7,15)$

\section{Beslenme eğitiminde öncelikli konular ve öneriler}

- Karbonhidrat, protein, yağ içeren besinler, karbonhidratlar ve kan glukoz düzeyi ilişkisi: Karbonhidrat içeren besinler, içecekler ve endojen/eksojen insülin postprandial glukoz kontrolünün ana belirleyicileridir. Diyabetli birey, tam taneli tahıllar, nişastalı sebzeler, meyve, süt, süt ürünleri (peynir hariç), sebze ve sofra şekerinin karbonhidrat içerdiğini, doymuş yağ ve trans yağ içeren besinler yerine tekli ve/veya çoklu doymamış yağ asitlerini içeren besinleri tercih etmesi gerektiğini bilmelidir. Hayvansal kaynaklı protein gereksinimini karşılamak için yağ içeriği yüksek olanlar yerine az yağlı veya yağsız olanları tercih etmelidir.

- Ambalajlı besin tüketimi, besin etiket bilgilerinin değerlendirilmesi: Karbonhidrat içeren bir besin tüketileceği zaman tuz, yağ, sukroz, glukoz şurubu vb. eklenmiş işlenmiş / ambalajlı besinler yerine yüksek posalı, besleyici değeri yüksek olan karbonhidrat kaynaklarının tüketilmesi önerilir. Besin etiketini okuma ve değerlendirme becerisi geliştirilir.

- Vücut ağırlık yönetimi: Vücut ağırlığında azalma sağlamak ve yönetmek için porsiyon kontrolünün, besin çeşitliliğinin önemi, sukroz, glukoz ve yüksek fruktozlu mısır şurubu ile tatlandırılmış içeceklerin tercih edilmemesinin gerekliliği vurgulanir.

- Hipoglisemi tedavisi: Hipoglisemi nedenleri ve tedavisi hakkında bilgi verilir.

- Besin takviyesi ve bitkisel desteklerin kullanımı: Kanıtlar yetersiz olduğundan diyabet tedavisinde yetersizlik saptanmamısssa vitamin ve mineral desteği önerilmez. Tamamlayıcı ve alternatif tedavilerin, bitkisel ürünlerin tedaviyi sağlayan hekim ve diyetisyene danışılmadan kullanılmaması gerektiği vurgulanır.

- Tuz tüketimi: Sodyum alımının azaltılmasına (2300 mg/gün) yönelik öneriler verilmelidir.

antropometrik ölçümler, biyokimyasal veriler, beslenme odaklı fiziksel bulgular, edinilen bilgi, davranış değişikliğidir. Değerlendirme kaynakları diyabetli bireyin kendi kendine izleme verileri veya formlar, elektronik tablolar ve bilgisayar programları, diğer kayıtlardaki veriler, antropometrik ölçümler, biyokimyasal veriler, tıbbi testlerdir. İzlem verileri anket uygulamaları (ön test/son test), telefon ve e-posta ile de sağlanabilir. İlk görüşmede, bir sonraki görüşmede izlenecek ve değerlendirilecek uygun sonuçlar/göstergeler seçilir. Sonraki görüşmelerde bu sonuçlar/göstergeler, kaydedilen ilerlemenin miktarını ve hedeflerin veya beklenen sonuçların karşılanıp karşılanmadığını göstermek için kullanılır $(11,16)$.

İzlem görüşmelerinde beslenme müdahalesinin öngörülen şekilde uygulanıp uygulanmadığı belirlenir. Müdahale stratejisinin diyabetli bireyin davranışını veya durumunu değiştirdiğine veya değiştirmediğine dair kanıtlar, elde edilen olumlu veya olumsuz sonuçlar diyabetli bireyle paylaşılır. Hedefe ulaşımı engelleyen nedenlerle ilişkili bilgi sağlanır. Çözüm yolları geliştirilir. Uygulamalarla ilişkili sonuç ve göstergeler değerlendirilir. Mevcut bulgular önceki durumlarla, müdahale hedefleri ve referans değerlerle veya standartlarla karşılaştırılır (11).

$\mathrm{Bu}$ aşamada besin tüketim kayıtları ile açlık ve tokluk kan glukozu izlem sonuçları arasındaki ilişki diyabetli bireye açıklanarak, birlikte değerlendirilir. Tıbbi tedavideki mevcut değişikliklere göre gerekirse öğün zamanı ve öğün içeriği yeniden planlanır. Uygulamaların değerlendirilmesi esnasında beslenme tanısı ve tanıya yönelik tedavi hedefi değişebilir. Belirlenen yeni tanı ve tedavi hedefine uygun beslenme müdahalesi içeriği gerekli öneriler ile birlikte beslenme eğitiminin verilmesini kapsar. İlerleyen zaman içinde saptanan yeni hedefe ulaşım izlenir (15).

TBT'nin etkinliği, tedaviye başladıktan sonraki 6. hafta ila 3. ay içinde değerlendirilir. Üçüncü ay sonunda glisemik kontrolde klinik bir iyileşme saptanmamışsa diyetisyen, medikal tedavinin değerlendirilmesi için hastayı hekime yönlendirmelidir (7).

Diyabet tanısı alarak diyetisyene yönlendirilen yetişkin diyabetli bireyde TBT’nin uygulanması 3-6 ay içinde tamamlanan, her biri 45-90 dakika süren 3-4 viziti kapsar. Yaşam tarzı değişikliklerinin desteklenmesi ve tedavinin değerlendirilmesi için 
yılda en az bir görüşme yapılarak devam edilmelidir. Gerekli durumlarda diyetisyen görüşme sayısını ve süresini değiştirebilir (17).

\section{Tibbi Beslenme Tedavisi Veren Diyetisyenin Sorumlulukları}

Diyabetli bireylerin tanı esnasında ve yaşam boyunca ihtiyaç olduğunda diyabete yönelik beslenme tedavisi konusunda bilgili ve deneyimli bir diyetisyenden beslenme tedavisi almaları önerilir (17-20). Bireysel beslenme planı belirlenen bir enerji (kalori) değeri üzerinden makro besin ögelerinin dağılımının yapılması değildir. Bireysel beslenme planı kapsamında verilecek kanıta dayalı önerilerin, bireyin beslenme davranışının değerlendirilerek planlanması TBT’yi sağlayan diyetisyenin sorumluluğudur. Diyetisyen, beslenme tedavisinin sonuçlarını tanımlanmalı ve etkinliğini sürekli olarak değerlendirmelidir (7). Diyabetli bireyin diyetisyene gitmesini öneren hekimler ile TBT'yi sağlayan diyetisyenlerin, diyabetli bireyin güvenilir ve kaliteli TBT hizmeti alması için gerekli sorumlulukları Tablo 4'de verilmiştir (20).
Tip 1 ve tip 2 diyabetliler tanıyı izleyen ilk bir ay içinde, gestasyonel diyabet tanısı alan kadınlar ise tanıyı izleyen ilk bir hafta içinde medikal tedavi, laboratuvar bulguları, tedavi hedefleri kayıtları ile birlikte TBT için diyetisyene sevk edilmelidir. Diyetisyen, bakım sürecinde her hasta için 'Beslenme Tedavisi Değerlendirme ve İzlem Formu' üzerinde gerekli kayıtları tutmalıdır (15).

Diyetisyenler TBT için diyabetli bireyle ilk 6 ay içinde 3-6 görüşme uygulamalı ve bireye özgü bir değerlendirmeye dayalı olarak ek TBT görüşmesi gerekip gerekmediğini belirlemelidir. Toplamda 6 ay içinde 2-16 saat süreyi kapsayan 3-11 kez TBT görüşmesinin HbA1c düzeylerini tip 2 diyabetli yetişkinlerde \%0.3-2.0 ve tip 1 diyabetli yetişkinlerde \%1.0 -1.9 oranında düşürdüğü bildirilmektedir. Altı aydan uzun süren çalışmalar ile TBT görüşmelerinde ki devamlılığın, HbA1c düzeylerinde sağlanan azalmanın korunması ve var olan azalmanın sürdürülmesinde tip 1 diyabetli yetişkinlerde 6.5 ylla kadar, tip 2 diyabetli yetişkinlerde 2 yıla kadar etkili olduğunun gösterildiği vurgulanmaktadır (10). Kanıta dayalı TBT ile oral antidiyabetik ilaç dozunun ve

Tablo 4. Hekimlerin ve diyetisyenlerin TBT ile ilişkili sorumlulukları (20)

\section{Hekimlerin sorumlulukları}

- TBT için hastayı diyetisyene yönlendirmek.

- Referans verileri sağlamak: Diyabet tedavisi; HbA1c, açlık glukoz düzeyi, kolesterol fraksiyonları, mikroalbuminüri düzeyini içeren laboratuar sonuçları; kan basıncı; medikal öyküsü; tedavi hedefleri, TBT’yi etkileyebilecek ilaç tedavisi.

- Medikal tedavi hedeflerini diyabetli bireyle paylaşmak ve temel beslenme mesajlarını desteklemek.

- Fiziksel aktivite için onay vermek.

- Eğer gerekliyse beslenme müdahalesinin sonuçlarına göre medikal tedavide gerekli düzenlemeleri yapmak.

\section{Diyetisyenlerin Sorumlulukları}

- Beslenme müdahalesi öncesi gerekli verileri ve tedavi hedeflerini sağlamak.

- Diyabetli bireyin TBT için finansal bir kaynağı olup olmadığını belirlemek.

- Besin tüketimi, fiziksel aktivite düzeyi, kan şekeri ölçüm sonuçları, psikososyal ve ekonomik şartları ile ilişkili verileri sağlamak ve değerlendirmek.

- Bireyin bilgi ve beceri düzeyini, gerekli değişimlere istekliliğini değerlendirmek, tedavi hedeflerini belirlemek.

- Uygun beslenme önerilerini belirlemek ve uygulamak, uygun eğitim materyalini kullanarak besin/öğün planına dayalı olarak öz yönetim eğitimini sağlamak.

- TBT’nin etkinliğini değerlendirmek ve uygun olan TBT’yi düzenlemek.

- Beslenme tedavisinin sonuçlarına göre hekime önerilerini iletmek.

- Ekip üyeleri ile sonuç ve gelişmeleri paylaşmak.

- İlk görüşmeden sonraki 3 ayın sonunda HbA1c sonuçlarını değerlendirmek.

- Hangi hastanın temel bakımdan faydalanacağına, hangisi ile daha sık olarak görüşülmesi gerektiğine karar vermek.

- Takip ve sürekli eğitim için gerekli planı yapmak. 
kullanılan ilaç sayısının azaldığı ve yaşam kalitesinin arttığı bildirilmektedir (21). Metabolik ve maliyet etkinliği kanıtlanmış olan TBT, bir hekim tarafından diyetisyene yönlendirilmesi ön koşulu ile Amerika'da 2002 yılında sağlık sigortası kapsamına alınmıştır. Sağlık giderlerine sağladığı katkı göz önüne alınarak 2006 yllında telesağlık ve 2011 yılında gruplara uygulanan TBT geri ödemeye uygun hizmetler grubuna alınmıştır (22).

\section{Diyetisyenlerin Mesleki Performans ve Uygulama Standartları}

Amerikan Beslenme ve Diyetetik Akademisi, akademinin kalite yönetimi komitesi rehberliğinde, diyabet tedavisinde diyetisyenlerin mesleki performans standartlarını ve uygulama standartlarını belirlemekte ve güncelleştirmektedir. Bu standartlar, diyetisyenler tarafından öz değerlendirme yapmak, mesleki gelişimlerini ve uygulamalarını ilerletmek için kullanılan araçlardır. Standartlar kapsamında diyetisyenlerin performansı yetkili, yetkin ve uzman olarak tanımlanmaktadır (23).

Yetkili diyetisyen: Mesleğini uygulama yetkisini almış, mesleki uygulamalarının ilk üç yılında olan, beslenme ve diyetetiğin tüm alanlarında uygulama bilgi becerilerini geliştiren bir diyetisyen (pratisyen diyetisyen) olarak tanımlanmaktadır. Ayrıca diyabet dışında başka alanlarda deneyimli olsa da yeni çalışma alanı diyabet olan diyetisyenler mevcut performansları nedeni ile bu grupta yer alır.

Yetkin diyetisyen: Genellikle mesleğe girişinin üçveya daha fazla yll ötesinde olan, sürekli olarak güvenilir hizmet sunan, iş performansı becerilerini kazanmış ve seçtiği odak uygulama alanında başarılı olan bir diyetisyen olarak tanımlanmaktadır. Beslenme ve diyetetik uygulamasının odak alanında ek bilgi, beceri ve deneyime sahiptir. Diğer bir ifade ile odak alanı diyabet ise diyabet tedavisi ve yönetimi konusunda ek bilgi ve uygulama deneyimi kazanmıştır. Ayrıca sertifikalı diyabet eğitimcisi (Certificated Diabetes Educator [CDE]) kimliğini almış olabilir. Akademi, Diyabet Eğitimcileri Ulusal Sertifikasyon Kurulu'nun
2017 yllında CDE’lerin \%41'inin diyetisyen, \%50'sinin hemşire, \%7'sinin eczacı ve \%2'sinin diğer disiplinlerden oluştuğunu bildirmiştir (23).

Uzman diyetisyen: Meslek içinde tanınan, beslenme ve diyetetik konusunda en üst düzeyde beceri ve bilgiye sahip olan bir diyetisyen olarak tanımlanmaktadır. Uzman düzeyinde başarı, uygulamanın sürekli eleştirel değerlendirmesi ve gelen geri bildirimler yoluyla elde edilir. Bu düzeydeki kişi ek bilgi, deneyim ve eğitim için çaba gösterir. Bir uzman, "ne” olduğunu ve duruma "nasıl” yaklaşacağını hızlı bir şekilde tanımlama yeteneğine sahiptir. Beslenme ve diyetetik becerilerini kolayca kullanır, yüksek derecede mesleki özerkliği ve sorumluluğu vardır. Diyabet bakımı ve yönetiminde uzman düzeyinde bir diyetisyen, prediyabet ve diyabetli bireylerin bakımı ve yönetimi konusunda geniş bilgi ve uygulama deneyimlerine sahiptir. Ayrıca, CDE ve/veya Gelişmiş Diyabet Yönetim Sertifikası (Board Certified-Advanced Diabetes Management [BC-ADM]) gibi bir veya daha fazla sertifikaya sahip olabilir (23).

Beslenme tedavi sürecinde izlenecek adımlarda, diyetisyenler performans standartlarına dayalı olarak uygulama yapabilmektedir. Akademi, hazırlamış olduğu standartlarla; bir diyetisyenin yetkili, yetkin ve uzman seviyelerinde güvenli, etkili ve kaliteli diyabet bakımı ve hizmeti sağlamak için hangi bilgi, beceri ve yeterlilikleri göstermesi gerektiğini belirlemiştir. Böylece, diyetisyenlerin, daha yüksek bir uygulama seviyesine ilerlemek için potansiyel eğitim ve öğretim ihtiyaçlarını belirlemelerine, özdeğerlendirmelerini gerçekleştirmelerine olanak sağlanmaktadır. Diyabet tedavisinde diyabetli bireyin besin tüketiminin değerlendirilmesi, besin tüketimi ile tokluk kan şekeri, HbA1c düzeylerinin yorumlanması ve karar verme mekanizmalarının uygulanması, diyabetle ilişkili yaşam tarzı davranışlarının değerlendirilmesi, tedavi hedeflerinin saptanması gibi uygulamaların sadece yetkin ve uzman diyetisyenler tarafindan yapılabileceği standartlar kapsamında belirlenmiştir. Aynı şekilde, komplikasyonların gelişiminin önlenmesi ve tedavisi için diyabetli bireyin tedaviye istekliliğinin değerlendirilmesi, diyabet 
ve ilişkili komplikasyonlar için beslenme tanısında önceliklerin belirlenmesi, diyabet ekibi ve diğer paydaşlar ile diyabet eğitiminde yer alacak beslenme konusunun içeriğinin planlanması ve yönetilmesi, $\mathrm{KH}$ sayımı yönteminde insülin / $\mathrm{KH}$ oranının ve insülin duyarlılık faktörünün saptanması gibi birçok uygulama sadece uzman diyetisyenler tarafindan gerçekleştirilebilmektedir (23).

Akademi, odak alanı diyabet olan diyetisyenlerin performans ve uygulama standartlarının belirlenmesinin, diyabet bakım kalitesinin artmasında ve diyetisyenin tedavideki etkinliğinin gösterilmesinde önemli olduğunu vurgulamaktadır (23).

\section{SONUÇ VE ÖNERILER}

Diyabet ve beslenme tedavisi konusunda bilgili, deneyimli ve eleştirel düşünme becerisine sahip diyetisyen tarafından sağlanan TBT, metabolik sonuçların iyileştirilmesinde, diyabetin önlenmesinde, prediyabetten diyabete ilerlememenin geciktirilmesinde ve diyabetle ilişkili komplikasyonların önlenmesi ve tedavisinde etkilidir. İşbirlikçi bir anlayışla, yatarak ve ayaktan sağlık hizmeti veren kurumlarda, diyabet merkezlerinde, Toplum Sağlığı ve Aile Sağlığı Merkezleri'nde diyetisyenin TBT hizmeti sunması sağlanmalıdır. Diyabet odaklı tedavi hizmeti veren diyetisyenler güvenilir ve kaliteli hizmet sunmak için gereken yeterliliklerini, uygun bilgiye sahip olup olmadığını kendi kendine değerlendirmeli, ek bilgi, beceri ve deneyime olan gereksinimini belirlemeli, iletişim becerisini geliştirmelidir.

Ülkemizde de Beslenme ve Diyetetik lisans eğitimi veren yükseköğrenim kurumlarının sayısı, sınırlı akademik personele rağmen oldukça artmıştır. Mesleki performans standartlarımız ve uygulama standartlarımız tanımlanmamış olduğundan mevcut şartlarda diyabetli bireylerin güvenilir ve etkili TBT almasını sağlamak için çözüm yolları geliştirilmelidir. Diyabet ve diyabet dışındaki klinik uygulama alanlarında çalışan yeni mezun olmuş, akademinin tanımına göre yetkili olan diyetisyenler için vaka çözümlü kurs programlarının planlanması faydalı olabilir. Minumum 2-3 yıl diyabet odaklı çalışan diyetisyenler ve yine akademinin tanımına göre yetkin olan diyetisyenler için ise teorik ve uygulamalı, yapılandırılmış eğitim programları ile multidisipliner sertifika kurulunca verilecek sertifikall diyabet diyetisyenliği programlarına gereksinim vardır. Sertifikalı diyabet diyetisyenlerinin tedavi sürecindeki etkinliği sertifika kurul tarafından değerlendirilerek sertifika güncellenmesi sağlanabilir. Diyabet Diyetisyenliği Derneği Sertifikasyon Kurulu, 2020 yılında, akademin bu tanımına uygun olarak, 'Diyabet Diyetisyenliği Sertifikasyon Programı'nı başlatacaktır. Sertifika programının katılımcılarının, Amerikan Diyabet Eğitimcileri Derneği ve Beslenme ve Diyetetik Akademisi sertifika programlarında olduğu gibi odak alanı diyabet olan diyetisyenler olması hedeflenmektedir.

Çıkar çatışması - Conflict of interest: Yazarlar çıkar çatışması olmadığını beyan ederler. - The authors declare that they have no conflict of interest.

\section{KAYNAKLAR}

1. TEMD Diabetes Mellitus Çalışma ve Eğitim Grubu. TEMD Diabetes Mellitus ve Komplikasyonlarının Tanı, Tedavi ve İzlem Kılavuzu-2019. 12. Baskı. Ağustos 2019-ANKARA

2. International Diabetes Federation. Diabetes Atlas Ninth Edition 2019. Available at: https://www.diabetesatlas. org/upload/resources/2019/IDF_Atlas_9th_Edition_2019. pdf Accessed Dec 25, 2019.

3. Satman I, Omer B, Tutuncu Y, Kalaca S, Gedik S, Dinccag N, ve ark. TURDEP-II Study Group. Twelve-year trends in the prevalence and risk factors of diabetes and prediabetes in Turkish adults. Eur J Epidemiol. 2013;28(2):169-80.

4. Andel M, Grzeszczak W, MichalekJ, Medvescek M, Norkus A, Rasa I, et al. DEPAC Group. A multinational, multicentre, observational, cross-sectional survey assessing Diabetes Secondary Care in Central and Eastern Europe (DEPAC survey). Diabet Med. 2008;25(10):1195-203.

5. Pablos-Velasco P, Parhofer KG, Bradley C, Eschwege E, Gonder-Frederick L, Maheux P, et al. Current level of glycaemic control and its associated factors in patients with type 2 diabetes across Europe: data from the 
PANORAMA study. Clin Endocrinol. 2014;80:47-56.

6. American Diabetes Association. Improving care and promoting health in populations: Standards of Medical Care in Diabetes-2020. Diabetes Care 2020;43(Suppl. 1):S7-S13.

7. Franz MJ, Reader D, Monk A. Implementing Group and Individual Medical Nutrition Therapy for Diabetes. American Diabetes Association. Alexandria, Virginia, 2002.

8. Myers EF. Nutrition care process and model and the international dietetics and nutrition terminology. What do they have to do with public policy? Nutr Today. 2014;49(1):26-31.

9. Academy of Nutrition and Dietetics. Definition of Terms List, September, 2019 Approved by Definition of Terms Task Force Quality Management Committee. https:// www.eatrightpro.org/-/media/eatrightpro-files/practice/ scope-standards-of-practice/20190910-academydefinition-of-terms-list.pdf. Accessed Dec 25, 2019.

10. Franz MJ, MacLeod J, Evert A, Brown C, Gradwell E, Handu D, et al. Academy of Nutrition and Dietetics nutrition practice guideline for type 1 and type 2 diabetes in adults: Systematic review of evidence for medical nutrition therapy effectiveness and recommendations for integration into the nutrition care process. J Acad Nutr Diet. 2017;117(10):1659-79.

11. Swan WI, Vivanti A, Hakel-Smith NA, Hotson B, Orrevall Y, Trostler N, et al. Nutrition Care Process and Model Update: Toward Realizing People-Centered Care and Outcomes Management. J Acad Nutr Diet. 2017;117(12):2003-14.

12. Nutrition assessment snopshot. Available at: https:// www.ncpro.org/nutrition-assessment-snapshot. Accessed Dec 25, 2019.

13. Nutrition diagnosis snopshot. Available at: https://www. ncpro.org/nutrition-diagnosis-snapshot. Accessed Dec 25, 2019.

14. Nutrition intervention snopshot. Available at: https:// www.ncpro.org/nutrition-intervention-snapshot. Accessed Dec 25, 2019.
15. Diyabet Diyetisyenliği Derneği. Diyabetin Önlenmesi ve Tedavisinde Kanıta Dayalı Beslenme Rehberi 2019. İstanbul; 2019.

16. Nutrition monitoring and evaluation snapshot. Available at: https://www.ncpro.org/nutrition-monitoring-andevaluation-snapshot. Accessed Dec 25, 2019.

17. Evert AB, Boucher JL, Cypress M, Dunbar SA, Franz MJ, Mayer-Davis EJ, et al. Nutrition therapy recommendations for the management of adults with diabetes. Diabetes Care. 2014; 37 (Suppl 1): S120-S143.

18. American Diabetes Association. Comprehensive medical evaluation and assessment of comorbidities: Standards of Medical Care in Diabetes-2020. Diabetes Care. 2020;43(Suppl.1):S37-S47.

19. American Diabetes Association. Facilitating Behavior Change and Well-being to improve health outcomes: Standards of medical care in diabetes-2020. Diabetes Care. 2020;43(Suppl.1):S48-S65.

20. Monk A, Barry B, McClain K, Weaver T, Cooper N, Franz MJ. Practice guidelines for medical nutrition therapy provided by dietitians for persons with noninsulin-dependent diabetes mellitus. J Am Diet Assoc. 1995;95(9):999-1006.

21. Franz MJ, MacLeod J. Success of nutrition-therapy interventions in persons with type 2 diabetes: challenges and future directions. Diabetes Metab Syndr Obes. 2018;11:265-70.

22. Step-by-Step Guide to Medicare Medical Nutrition Therapy (MNT) Reimbursement 2nd Edition, April 2010. Available at:https://www.ihs.gov/sites/diabetes/ themes/responsive2017/display_objects/documents/ clinicaldocs/MNT_Reimburse_Guide_508c.pdf. Accessed Dec 25,2019.

23. Davidson P, Ross T, Castor C. Academy of Nutrition and Dietetics: Revised 2017 Standards of Practice and Standards of Professional Performance for Registered Dietitian Nutritionists (Competent, Proficient, and Expert) in Diabetes Care. J Acad Nutr Diet. 2018;118(5):932-46. 